\title{
The Constitution of a Transnational Policy Field Negotiating the EU Internal Market for Products
}

Højbjerg, Erik; Frankel, Christian

Document Version

Final published version

Publication date:

2004

License

CC BY-NC-ND

Citation for published version (APA):

Højbjerg, E., \& Frankel, C. (2004). The Constitution of a Transnational Policy Field: Negotiating the EU Internal Market for Products. Department of Management, Politics and Philosophy, CBS. MPP Working Paper No. $10 / 2004$

Link to publication in CBS Research Portal

\section{General rights}

Copyright and moral rights for the publications made accessible in the public portal are retained by the authors and/or other copyright owners and it is a condition of accessing publications that users recognise and abide by the legal requirements associated with these rights.

Take down policy

If you believe that this document breaches copyright please contact us (research.lib@cbs.dk) providing details, and we will remove access to the work immediately and investigate your claim. 
The Constitution of a Transnational Policy Field Negotiating the EU Internal Market for Products

Erik Højbjerg \& Christian Frankel WP 10/2004 
MPP Working Paper No. 10/2004 @

September 2004

ISBN: 87-91181-80-1

ISSN: 1396-2817

Department of Management, Politics and Philosophy

Copenhagen Business School

Blaagaardsgade 23B

DK-2200 Copenhagen N

Denmark

Phone: +45 38153630

Fax: $\quad+4538153635$

www.mpp.cbs.dk 


\title{
The Constitution of a Transnational Policy Field - Negotiating the EU Internal Market for Products
}

\author{
Christian Frankel \\ Department of Organization and Industrial Sociology \\ $\&$ \\ Erik Højbjerg \\ Department of Management, Politics and Philosophy
}

\begin{abstract}
The EU internal market has predominantly been studied in terms of changes in delegation of authority and division of labor between EU institutions and member states. However, this EU internal focus ignores that already in 1987 the completion of the internal market was substantially left to the private European standardization organizations (ESO). The paper addresses two fundamental challenges in this transnational, public-private, and internal-external delegation of authority. First, it involves a governance challenge, because private actors are directly involved - but to a certain extent outside EU political and administrative control - in the constitution of the internal market. Second, the delegation raises important analytical questions concerning the identification of the institutional locus of European integration, when the realization of the political goals with the internal market is dependent on an inter-organizational coordination between the EU and ESO. Applying the analytical concept of a 'policy field' the analysis shows how the completion of the internal market fundamentally challenges institutionalized conceptions of the role of politics in constituting markets.
\end{abstract}




\section{Keywords:}

Internal market, policy field, technical standards, transnationalization, new approach harmonization, private product policy 


\section{Introduction}

In this paper we present an argument justifying an increased focus on aspects of private political enterprise in European integration. We find that there is ample empirical evidence, and an analytical potential in, suggesting that private sector actors play an increasingly systematic role in constituting (and regulating) the political institutions of European integration. The influence goes beyond issue-specific lobbying (Mazey \& Richardson 1993b, Pedler 2002) as well as 'iron-triangles' of corporatist arrangements (Gorges 1996, Pedersen \& Pedersen 1995). It exceeds particular Public-Private Partnerships of service delivery (Börzel \& Risse 2001) and problem-oriented governance networks (Kohler-Koch \& Eising 1999, Börzel 1998, Dowding 1995, Rhodes, Bache, \& George 1996). Our argument questions the more or less implicit assumption common to these theoretical and analytical perspectives; that the fundamental boundary between public and private is essentially unaffected (and hence endorsed) in the different forms of cross-boundary interaction. In our view, a debate is needed on to what extent the public-private boundary is undergoing fundamental changes in the ways it organizes the articulation of political aspirations. Perhaps the imagery of the liberal state, dividing civil society and economy from public authority, today is only a myth. Under the heading of 'governance', 'New Public Management', or even 'good governance' current responsiveness of traditional political and governmental institutions, e.g. the administration, towards stakeholders and 'affected interests' has reached a scale, where accountability is no longer a question simply of $e x$ post judicially scrutinizing the exercise of public authority, but a commitment ex ante to engage all formulated and potential political interests in the formation, decision, implementation, and revision of policies. Interestingly, however, this responsiveness also characterizes a growing number of civil society institutions, i.e. private enterprises, NGOs, and with particular reference to this paper, European standardization organizations. The resulting image of the 'blurring' of the public-private boundary is well known. However, what is not well known for lack of analysis, are the ways in which this 'blurring' affects our conception of politics and political agency, of democratic legitimacy and accountability, and of European integration.

What we call for, then, is a debate. The debate should first and foremost be oriented towards developing analytical strategies for diagnosing the varying conditions, under which 
private actors articulate and pursue political strategies and hence, under what conditions private actor political enterprise becomes meaningful in relation to European integration. An adequate diagnosis of the current conditions for private political enterprise can establish an informed basis for further theorizing on European integration.

The goal of this paper is therefore, as a first step, to develop an analytical perspective to processes of European integration, in which politics is not defined theoretically as an 'input' - or independent - variable to analysis, but rather where politics is the dependent variable describing the output of analysis: Politics is not what our theories tell us it should be, but what actors themselves make of it! It is important to stress that our analytical perspective is consciously as minimal as possible in order to be able to grasp the widest set of empirical indications of the politization of private actors in European integration processes. In this sense, David Easton's classic definition of politics as collectively binding decisions (1981) serves this purpose.

In order to both develop and justify this analytical perspective, we need firstly to identify the specific context of analysis. We do not assume that there are general conditions for the politization of private actors in European integration processes. An adequate diagnosis must rest on an analysis of the specific contexts in which politization can occur. In the next section we present the case of the internal market for products as a particularly interesting context for the politization of private actors in European integration processes. We suggest that this context can be analyzed with the analytical category of policy field, denoting a specific relational system of political struggle between mutually autonomous actors and institutions. In section 3 we show how in 1985 the conditions for a policy field was established with the adoption of the Council Resolution 'New approach to technical harmonization and standards' establishing institutions and procedures for a division of work between the 'public' EU and the private European standardization organizations in relation to the internal market for products. On this basis, in section 4, we claim that within this system, the European standardization organizations subsequently developed an independent private product policy, challenging the EU's political objectives with the internal market. Finally, in section, 5 we present two brief examples of how such challenges are managed in the policy field, leading to a diagnosis of a transnationalization in the way political processes are organized. 


\section{Observing the internal market}

Political and administrative science studies of the preconditions for the completion of the European internal market have predominantly focused on changes in the internal division of competencies between existing EU institutions and member states. However, this EU internal focus ignores that already in 1987, with the adoption of the Single European Act, a substantial part of the completion was left to the private European standardization organizations $\left(\mathrm{ESO}^{1}\right)$. Instead of adopting detailed legislation for individual products the EU member states agreed on framework legislation, specifying essential requirements for marketing broad product groups, leaving the detailed technical specifications for these requirements to ESO. In this way, the completion of the internal market was preconditioned on an institutional coordination between mutually autonomous private and public international actor constellations. Despite the fact that the internal market program, i.e. the legislative basis for the internal market, was by and large completed within the magic time frame of 1993, the internal market to this day is still under construction. One of the reasons is that the technical standards ESO was originally commissioned to develop have still not been completed. The de facto realization of the internal market is therefore dependent on a transnational coordination, which not only has an influence on when the market is completed, but also - and perhaps more importantly - how it will look. In view of the important role ESO were given in the completion, and indeed still hold in the on-going revision, of the internal market, it is remarkable that this delegation has thus far not been appreciably studied in terms of its political, and in particular politicizing, aspects vis-à-vis private actors. The delegation not only seems to contain democratic challenges, because private actors through membership of the autonomous ESO participate directly, and to a certain extent beyond political and administrative scrutiny, in the establishment of the rules for marketing products in the internal market. It also raises important analytical questions concerning how to identify the institutional locus of European integration, when the

\footnotetext{
${ }^{1}$ The European standardization organizations comprise the European Committee for Standardization (CEN), the European Committee for Electrotechnical Standardization (CENELEC), and the European Telecommunications Standards Institute (ETSI). Agreements on mutual recognition of standards have been adopted between these three organizations and although differences in organization and decision-making procedures exist it seems reasonable to view them as a whole. It should be noted, however, that in terms of level of activity CEN by far constitutes the biggest of the three organizations and when the paper refers to ESO it will therefore primarily involve CEN.
} 
realization of EU's political objectives with the internal market is directly dependant on creating institutions for an inter-organizational coordination between the mutually autonomous EU and ESO.

Hence, there seems to be good reasons for studying the constitution and functioning of these institutions and in particular, to what extent they have changed the institutional capacity of the EU to pursue its internal market policy.

In 2001 the Journal of European Public Policy devoted a special issue to the political and economic aspects of international institutional standards setting, thus making an important contribution to placing international standardization on the political science agenda. In itself, the publication of the special issue can be viewed as an indication of the gradual scientific acknowledgement that international standardization is of growing political salience. Although no single contribution focuses exclusively on the EU-ESO institution building in relation to the completion of the EU internal market, it is included in several contributions as an example of some of the problems related to the governance of international standards setting.

Governance, defined in the issue's introduction by Walter Mattli as "...the formal and informal bundles of rules, roles, and relationships that define and regulate the social practices of state and non-state actors in international affairs" (2001 p. 332), is therefore the basic analytical concept applied in the contributions. To the extent - as claimed by Mattli - that studies by economists and legal scholars lacks analysis of political and institutional factors and that political scientists have neglected the field altogether, applying the analytical concept of governance seems more than appropriate in opening up a relatively new field of analysis, characterized by ambiguity in the roles played by actors across national and international levels as well as across public and private spheres of activity.

However, the analytical mapping out of different governance problems must be seen in relation to the issue's clearly stated theoretical ambition. In the introduction, Walter Mattli stresses the need for a consistent theoretical argument "...to explain or assess institutional standards arrangements..." that will give guidance for policy-makers and private 
entrepreneurs alike in choosing "...optimal institutional design" (2001 p. 331, emphasis in original), suggesting that the contributions in the special issue are primarily informed by a rational choice institutionalism. In our reading, therefore, the fundamental problem addressed in the special issue seems to be that the current situation of international standardization is plagued by such governance 'deficiencies' that significant global welfare gains are lost, or, in other terms, that there are obvious political and economic potentials for designing institutional arrangements that will produce greater global welfare gains from international standardization.

Given this theoretical ambition it is not surprising that the analytical framework takes as its point of departure a typology of the connectivity and externality problems creating the demand for international standards (Abbott \& Snidal 2001). Analytically, the category of governance is developed in order to empirically identify what types of institutional arrangements, i.e. specific 'bundles of social practices', that produces different types of connectivity and externality problems, the underlying (theoretical) assumption of course being that problems of connectivity and externality are essentially problems of coordination, or, in other terms, of collective action. In line with the rational choice institutionalism, politics is conceived as the process of selecting optimal solutions to collective problems.

Our analytical approach differs on at least three accounts. First, the context of analysis is defined along substantially narrower lines. Our analytical setup is designed in order to diagnosing current institutional conditions for the politization of private actors in European standardization governance arrangements specifically related to the completion of the internal market for products. It is not directed towards diagnosing general conditions for international public-private interaction in relation to standardization on a global or European level. Second, it is not prescriptive in the sense that it provides guidance for selecting optimal policy solutions, i.e. what actors should or should not choose to respond to different types of governance problems. In stead, we want to address how the actors themselves articulate problems, and the strategies they develop in order to deal with them. In this sense our approach is descriptive, informed by political, economic, and legal sociology (Fligstein \& Mara-Drita 1996, Fligstein 1996, Joerges, Ladeur, \& Vos 1997, Joerges, Schepel, \& Vos 1999, Snyder 1994), and it is inspired by elements of both 
discourse analysis (Andersen 2003) and institutional theory (Campbell \& Pedersen 2001, Pedersen 1991). Thirdly, we largely subscribe to the same definition of governance, but rather than developing this concept on the basis of externalities produced by international interaction, we put it into an analytical framework designed in order to identify how individual decisions made by mutually autonomous actors are coordinated with collective decisions within institutionalized conceptions of common European political interests. In other words, we want to understand how the organizational and institutional differentiation of the EU can be reconciled with complex forms of integration and coordination.

We will claim that in relation to the internal market policy for products there are sufficient empirical indications to justify that as a policy it escapes a clearly defined institutional or organizational ownership. It cannot be viewed as a clearly delineated policy sector, but seems to be characterized by a polycentric institutionalization (Willke 1992, Dehousse 1998). It is populated by actors in many, mutually autonomous centers, each formulating internal market policy conceptions and pursuing different strategies. The polycentric character of the internal market policy thus makes it an arena for political struggle, which is primarily mediated by mechanism that intertwine processes in autonomous centers without establishing hierarchical relations between them. No single actor has the institutional or organizational capacity to force through his individual strategies in the face of resistance.

Therefore, in order to identify the specific, contextual conditions for the politization of private actors in relation to the EU internal market policy for products, we will use as our basic analytical concept the category of policy field. A policy field can be viewed as a system of relations between political actors and institutions that struggle over something, which is common to them (This definition is inspired by Bourdieu \& Wacquant 1992 pp. 94115, Bourdieu 1994 p. 87, and Broady 1991 p. 266ff). A specific range of actors, a specialized set of institutions, a specific range of problem formulations, and a particular conception identify a policy field. It is characterized by particular criteria for access and behavior that are developed on the basis of processes, in which boundaries are set between policy fields. 
In analytical terms, a policy field can be empirically delineated by the particular ways in which a) policy formulation takes place; b) forms of organization have emerged; and c) modes of interaction have been established.

Policy formulation describes what in broad terms can be understood as the discursive aspect of the policy field. It reflects if and how political conceptions and ideals have been transformed to common understandings of policy problems and goal formulations. Forms of organization comprise the organizational aspects of the policy field, including if and how divisions of authority and competence have been established between national and international authorities and between public authorities and private actors in relation to the solution of common problems. Finally, modes of interaction are defined as the institutional aspects of the policy field, and focus on if and how institutional structures of interaction have been created. It sheds light on the modes, in which the interaction between political, administrative, scientific, and economic institutions are coordinated and governed.

Taken together these three categories cover the discursive, institutional and organizational aspects of a policy field. The field concept is consistent with the concept of governance in the sense that it addresses the political processes by which solutions to common problems are developed across different, mutually autonomous actor constellations. In identifying different modes of governance interaction we will place institutional coordination along a continuum ranging from 'hard' regulation to 'soft' coordination. 'Hard' regulation is characterized by conflict resolution through hierarchical organization. Decision-making is based on pre-given legislation, rules, and agreements specifying rights and duties. This implies that decisions can be made an object of authoritative control and legal sanction. By contrast, 'soft' coordination rests on communication that provides conflict resolution through the creation of common frames of reference. It entails a process where conflicts are not initially directed to enforceable decisions, but to influencing others' perception of their own interests, thus laying a foundation for future decision-making processes.

Here, one might ask what differentiates our concept of policy field from the concept of network, often used in recent studies of the institutional coordination of European integration. No doubt, the network concept is a powerful metaphor for describing the governance of complexity through coupling of actors structured around a multitude of 
formal and informal institutions in the 'gray zones' between the public and private sector (Kickert, Klijn, \& Koppenjan 1997, Chisholm 1989, Marsh \& Rhodes 1992). In particular, the policy network approach has been very successful in demonstrating how decisions in the EU are made in a fragmented system of bureaucratic politics (Peters 1992); how policy networks are constitute important arenas for agenda setting (Peterson 1995, Peters 1994); and it has been used in studies of implementation and lobbyism in different policy sectors, e.g. the structural funds (Marks 1992), the environmental policy (Richardson 1995, Mazey \& Richardson 1993a, Porter 1997), the technology policy (Peterson \& Rhodes 1992), and the telecommunications policy (Fuchs 1994, Schneider, Dang-Nguyen, \& Werle 1994).

What characterizes most of this literature, however, is that it assumes that public actors, i.e. the EU institutions and national governments with formal authority, constitute the 'natural' institutions for rule production and coordination within relatively isolated and clearly defined policies of European integration. Despite ascribing public-private networks an important influence in the creation and implementation of common European decisions, there nevertheless seems to be an implicit assumption that public authorities ultimately define the institutional frames for the integration process. The object of analysis is decisions made by the EU institutions and how they influence the direction and speed of changes in the division of competencies across different levels of community, regional, and national authority. Hence, there is a primary focus on negotiation and decision making processes aimed at empowering and changing the political competencies of EU institutions, while the negotiation processes by-passing the EU are either displaced as exogenous environmental conditions for European integration, or marginalized as irrelevant for the realization of EU political goals.

By contrast, with the concept of policy field we want to address how European political integration is influenced not only from the 'public inside' of the EU and its institutions, but also from the 'private outside' of its environment, and how the boundary is thus becoming a fundamental object of political struggle, with private actors assuming political functions.

In the next section we describe the formal governance structure that was initially set up for the completion of the internal market program for products. The structure, known as the 'New approach to technical harmonization and standards', established the organizational 
conditions for a formal procedure of coordination of public and private activities, and in this sense, it constituted the possibilities of a policy field for the internal market for products.

\section{The constitution of a policy field - 'New Approach', product regulation and technical standardization}

The systematic utilization of common European technical standards in EU-regulation was formalized by the Council with the "Resolution of 7th May 1985 on a new approach to technical harmonization and standards" (85/C 136/01). It formulated a new strategy for the establishment of the common market for products and the adoption of the Single European Act in 1986 made it an important foundation for the realization of the internal market.

In the resolution, the Council stated that the objectives pursued by member states for the protection of citizens' safety, health and the environment were principally the same, although the technical means for their completion were different. In other words, the similarity between the objectives on the European level and the differences between the instruments on the national level came to serve as the grounds for increased utilization of European technical standards in connection with product regulation.

Generally speaking, it had previously been national provisions and technical guidelines, for not to mention technical standards, that had to be fulfilled in order to market products in the Common Market. A number of these national provisions and standards were in practice seen as technical trade barriers, as products in every country were subject to separate demands, tests, and authorization before they could be marketed. ${ }^{2}$ This was the background for the Information procedure directive from 1983, the intention of which was to avoid and preclude technical trade barriers as arising from national provisions and standards. $^{3}$

\footnotetext{
${ }^{2}$ It has been estimated that the completion of the internal market would require the harmonization of more than 100.000 national regulations and standards, all of which could function as technical trade barriers (Goldschmidt 1995).

${ }^{3}$ The full title of this Council directive, which has since been subject to various revisions, is '83/189/EEC of 28 March 1983 laying down a procedure for the provision of information in the field of technical standards and regulations'
} 
The intention behind the New Approach resolution was therefore to provide the Community with an overall, formal framework with which to parry the establishment of technical trade barriers and to ensure the removal of those already existing.

Four principles for this objective were stated in the resolution. First, New Approach directives must only determine essential requirements related to health, safety, consumer interests and the environment for broad product groups. Second, the requirements are to be concretized by the European standardization organizations in harmonized technical standards. Third, the technical standards are voluntary. Fourth, the national administrations are obligated to accept the free movement of goods produced in accordance with the standards ('presumption of conformity'), but have a continued responsibility to secure the fulfilment of the directives' essential requirements.

The principles were (and indeed still are) to be fulfilled via a procedure with five basic steps. First, drawing up and adopting Community legislation; second, formulating the socalled standardization mandates on the background of the legislation's essential requirements; third, drafting of voluntary technical standards that concretize the mandates: fourth, EU approval of the harmonized European standards; fifth and finally, publication of the approval in the official journal, which simultaneously obligates member states to accept the free movement of goods produced in accordance with the standards.

The New Approach procedure can be set forth schematically in the following manner, where the numbered arrows refer to the different steps in the procedure:

\section{Public Private}

European level

National level

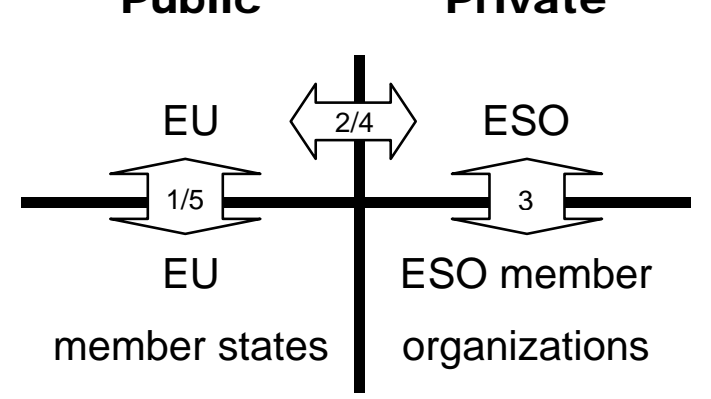

- Figure 1: The five steps in the New Approach 
The 'new' aspect of the New Approach procedure was that the technical means by which pan-European political goals are to be attained are no longer to be determined on the national level, as was previously the case, but rather, via harmonized European standards. On that background, it can be contended that the New Approach established a formal division of labor between the EU on the one side as framework legislation that obligates member states to formulate political objectives for the establishment of the European market, and on the other side, ESO, which via standardization mandates drafts and adopts voluntary technical standards that facilitate the realization of the European market. In this context it is worth noting that the division of labor involves a coordination of activities proceeding within two separate and formally autonomous institutional arrangements in both the public and private spheres.

EU member states governments participate via the Council of Ministers and its interplay with the Commission, the EU Parliament and the European Court of Justice in the preparation, adoption, and sanctioning of European legislation. Without engaging in a detailed accounting of the conditions under which EU legislation comes about, including, for example, the relative distribution of authority between member states and Community or private interests' influence on the legislative process, we merely wish to emphasize that, among other things, there is a national (territorial) principle for representation that forms part of the foundation for the realization of EU interests. In that sense, European legislation requires a national formation of preferences that is reflected in the negotiations in the Council of Ministers.

In the ESO, voluntary, pan-European technical standards are drawn up, as in the EU, according to a principle of national representation. ${ }^{4} \mathrm{ESO}$ is therefore based on the private, national standardization organizations in the EU and EFTA member countries, which send delegations of their members to represent them in ESO. While the national standardization organizations in principle are open for all interested parties, the sphere of members is typically comprised of commercial interests and to a lesser extent interest organizations and public authorities.

\footnotetext{
${ }^{4}$ The following presentation focuses on CEN and CENELEC since ETSI differs on this by being organized according to a combination of both national and functional representation.
} 
On the national level it must be ensured that the delegations' positions reflect significant national interests that can be linked to a standard. In instances where there is national interest in the drafting of a European standard, national coordination committees are appointed parallel to ESO-committees. The national organs are responsible for sending proposals for standards to consultation with the relevant authorities and other interested parties, and abstain from initiating standardization assignments within areas under consideration in ESO.

In the ESO the standardization process itself progresses in a decentral manner in socalled technical committees (TCs) with underlying working groups (WGs). A chairman, whose position is somewhat analogous to the EU-presidency, leads the TCs and WGs; the chairman is to primarily work for the achievement of consensus concerning a given standard. In practice, however, the chair is often used to advance special interests, as it is predominantly private industry that represents the national standardization organs in the chairman posts.

The standardization process is customarily a complicated affair necessitating numerous compromises and settlements. Several years are therefore often required from the commencement of a task until the TC can advocate a completed standard for consultation in the national standardization organs with subsequent revision and final adoption. The adoption of technical standards is determined by the casting of national votes. These votes are weighted as in EU Council of Ministers voting; in the absence of a qualified majority for the standard in question among the member organizations, it is investigated whether there is a qualified majority among the member organizations from the EU member states. Should this be the case, the technical standard is implemented in all EU member states, as well as in those EFTA countries that voted in favor of the standard in question. When the ESO has agreed upon a standard, the national organs are generally obligated to implement the standard as national standard and simultaneously withdraw potential parallel national standards.

Although the EU and ESO are separate organizations - each making decisions in different terms, by different actors and on the basis of different considerations and with different scope - the intention behind the New Approach was nevertheless to tie their activities 
together in a common purpose, namely the removal of technical trade barriers for products in the EU. In other words, the vision behind New Approach was one by which the removal of technical trade barriers could be realized by coordinating a public legislative process within the framings of the EU institutions with a private standardization process within the framings of the ESO. The formal organization of these coordinative efforts has been thoroughly accounted for elsewhere (Commission of the European Communities 2000, Vos 1999, Environmental Resources Management 1997, Scheel 1996, Jörissen 1996, Voelzkow 1996, Vad 1998). The point to be made here is merely that the specific form of the coordination was laid down in the second and fourth step in the New Approach procedure. We will address them in turn.

The second step involves the drafting of the standardization mandates. The mandate is the EU's 'commissioning' of standards from the ESO, and as such specifies the boundaries between the political and the technical. The mandates are formulated by the Commission on the background of an interpretation of the framework directives, including the specific assignments the EU wishes the ESO to conduct; the timeframe that is to apply to the assignments; the judicial foundation that the EU standards shall refer to (one or more directives or a given EU policy); and the extent to which - and in which form - the standardization work is to be made the object of EU financing. In this conjunction it is significant that it is the Commission's evaluation that forms the basis for the delineation of the boundaries between the political and the technical aspects in the formation of the European market. This is exactly where the political regulation of ESO's activities is the strongest - though not stronger than that the mandate is shaped in negotiations with the ESO. Two circumstances are quite central in these negotiations: First, the mandates merely determine the political objectives for the standards' content, not procedures for their creation (apart from setting the time frame). Secondly, within the division of labor there is no restriction on ESO's right to adopt European standards without a mandate from the EU. ESO therefore maintains their competence to develop standards on their own initiative. This demonstrates an asymmetry in the division of labor, as the EU lacks alternative standardization organizations to draw upon, while ESO is not obligated to assume tasks in relation to the EU. 
The fourth step deals with the EU's approval of the complete, mandated standards. Here it should be noted that according to the New Approach, EU-approval of the standards is not tied to an explicit approval procedure. Positive approval is only granted in cases where doubt lingers as to whether a harmonized standard in effect reflects the essential requirements of the directive. If the quality of a standard goes unchallenged by the Commission and the national administrations, approval is automatically granted (in other words, negative approval).

As such, New Approach determines a procedure that in steps two and four involves the coordination of public and private activities, which would otherwise transpire in an uncoordinated manner (see the figure above). It is characteristic for the coordination that it takes place on the European rather than the national level.

This presupposes firstly, that the national public interests are attended to in the drafting of EU framework directives, and that the mandates for standardization that are the basis for this work are sufficient to ensure the political regulation of the private European standardization organizations. As described above, New Approach does not determine the specific requirements concerning the creation of the standards, only their content.

Secondly, it presupposes that the ESO does not have an independent influence on which political objectives are to be fulfilled. When the Commission mandate has been drafted and accepted by ESO, the political interests have already been spelled out and considered. The subsequent standardization process is therefore a process that exclusively involves technical and not political considerations. This assumes then, that it is possible to draw an unambiguous boundary between political and technical considerations. From the EU perspective, the advantage with such delineation is that the EU can achieve full harmonization via framework legislation without being burdened with the drafting, negotiation and implementation of great quantities of detailed legislation.

Full harmonization means that the possibilities for independent public regulation as well as private standardization on the national level are exhausted within the areas covered by New Approach. As such, full harmonization means that both national authorities and 
national standardization organizations are referred to safeguarding their interests on the European level.

Insofar as national authorities wish to address public interests in the standardization process, they must do so via the national standardization organizations. In this manner, the national authorities' safeguarding of public interests in the ESO depends, in the first instance, on a private-public coordination on the national level. However, this national private-public coordination was not explicitly mentioned in the New Approach resolution.

The presentation of New Approach reveals how the division of labor was assumed to be unproblematic. It was assumed that it was possible to establish narrow couplings between EU legislation and voluntary technical standards without this necessarily having a bearing on the voluntary status of the standards (i.e. the third principle in New Approach). And it was further assumed - again, apparently as though this was not a problem - that it was possible to initiate a political regulation of ESO via the mandate, but within the framework of a division of labor that presupposes the ESO's autonomy.

In the following section we will demonstrate how both of these assumptions are encumbered with problems. Since 1987, a paradoxical mixture of stability and change has characterized the division of labor between the EU and the ESO. European standardization has altered its content and status, without changing the formal set-up concerning the division of labor. The narrow coupling between EU legislation and European technical standards has led to a situation in which the technical standards have received a de facto binding character and that European technical standardization has thereby developed into a 'private product policy'.

Before we proceed with our line of argument, let us sum up the analysis so far using the concept of policy field. With the adoption of the New Approach resolution in 1985 organizational and institutional conditions were established for the coordination of activities between two European organizational arrangements, the EU as an international legal order of its own and the ESO as organizations under international private law. The coordination was justified with reference to a specific problem formulation, namely that the differences in national provisions regulating the marketing of products among EU member 
states was detrimental in pursuing common political objectives for the internal market. The problem formulation rested on the discursive assumption that political objectives and technical means could be separated as distinct areas of public and private activity in relation to products and that each area could be defined as a specific organizational responsibility of 'service delivery' or production. On this basis a particular form of organization between the EU and ESO was established, leaving the public authority to define and control the political objectives for the internal market for products with the EU and the private competence to 'translate' these objectives into detailed technical standards with the ESO. In addition, institutional modes of interaction were set up, particularly in the institution of the standardization mandate, regulating the conditions under which the public aggregation of EU political interests should form the basis for the private aggregation of corresponding ESO technical considerations. In other words, the conditions for a policy field, in which a specific range of mutually autonomous, public and private actors were integrated in order to find common technical solutions to common political objectives, were established. At this stage, however, only the conditions for a policy field were established, since the discursive boundary between the political and the technical, or between public policy and private technology - on which the division of labor was predicated and justified in the first place - had not yet itself been subject of politization with consequences for the forms of organization and modes of interaction. In the following section, however, this is what we will suggest happened.

\section{The Development of a Private Product Policy}

There is no doubt that the sharp increase in European standardization has come about as a result of the objectives in New Approach and later in the implementation of the Single European Market Program. Whereas in 1984 - prior to New Approach - there were merely a total of 670 common European standards (DIN 1995 p. 5), there are now in excess of 14.000 standards and related documents in CEN and CENELEC alone, of which at least 3.800 are mandated, harmonized EU standards. ${ }^{5}$ The goal is to complete some 12.000 European standards following New Approach, which are to replace in excess of 100.000

\footnotetext{
${ }^{5}$ Numbers are deceptive and should be handled with care. These numbers have been generated by surfing the 'Facts \& Figures'-pages on the web of CEN (www.cenorm.be) and CENELEC (www.www.cenelec.org). The number of harmonized European standards in relation to New Approach has been estimated on the basis of the list of referring directives on the web of the Danish Standards Association (www.ds.dk).
} 
different technical regulation and standards on the national level prior to the implementation of the internal market (Goldschmidt 1995 p. 446).

While only roughly $25 \%$ of the European standards are mandated, it appears as though the EU has set an explosive development in motion by appointing ESO as a significant arena for the establishment of the internal market for products. It is hardly a surprise that New Approach has led to a violent reinforcement of the standardization capacity on the European level. It is debatable, however, whether the significance that European standardization has attained was foreseeable.

This significance can be illuminated with the help of two claims, which in conjunction with the scale of common European standards justifies a description of ESO's actual standardization activities with the term 'private product policy'. Firstly, technical standards now represent the only viable instrument for corporations to place products on the (internal) market of Europe. The claim is that technical standards have attained a binding character, even though they are formally still voluntary. Secondly, at the same time that technical standards attain a binding character, the standardization process not merely involves deliberations of a scientific, technical nature, but increasingly also the consideration of broader societal and political interests. The claim is that the standardization process is politicized in as much as it is not given beforehand that the standards are to fulfill technical considerations alone.

That European technical standards have attained a binding character may not be surprising since they displace national standards. For long, national technical standards have constituted a 'language' - a particular form of communication - that serves as the foundation for the exchange of goods in the national markets. A main reason for adopting the New Approach was, as mentioned above, that national technical standards were (and still are) perceived as trade barriers. In other words: National technical standards were perceived as soft law, requirements which effectively (although not legally) were binding. Studying the history of the New Approach, it seems clear that two different yardsticks are used when discussing the binding character of technical standards. First, national standards are measured by their effect, and it is concluded that in practice they have binding character. Second, European technical standards, by contrast, are measured by 
their legal status, and it is pointed out that from a legal point of view they are voluntary. However, as European technical standards displace national standards, it is to be expected that also European technical standards in practice will have binding effect, i.e. become soft law.

The soft law status of technical standards may also explain why private corporations participate in European standardization. Broadly speaking, it is possible to claim that initially corporations pay to participate in the drafting of technical standards, after which they are made to buy them from the national standardization organizations! While standards are to serve the 'common good', it cannot be taken for granted that corporations participate in standardization efforts solely on altruistic grounds. The individual corporation's participation can possibly be accounted for in terms of strategic advantages gained by forming the soft law that is to define future requirements for market access, in a manner better suited to the corporation's own products than those of their competitors. In this sense, private actors participate in technical standardization in order to influence the constitution of future conditions for competition on the market.

In addition, European technical standards have become 'soft law' also as an effect of their roles in a legal context. Since the adoption of New Approach, EU legislation has come to support the 'soft law status' of European standards in at least six ways, of which the first three are narrowly tied to mandated, harmonized standards according to New Approach:

Presumption of conformity. From the outset, with New Approach directives member states are obligated to assume that products certified in compliance with harmonized standards observe the directive in question. Harmonized standards then constitute a relatively stable foundation upon which to market products, as reasonable suspicions are required for a member state to cease the marketing.

Inverted burden of proof. The burden of proof for incongruity between a harmonized New Approach standard and a product lies with the member state. This favors harmonized standards as a means of insuring corporations' access to markets within required legislation. 
The directives' low degree of specification. The framework directives following New Approach open up for broad conflicts over interpretation, which make it difficult to document whether a product fulfills a directive's requirements in legal conflicts. Whether they do so can, to a great degree, only be determined through an interpretation of harmonized standards. The standards thereby become a secondary legal source in European Court of Justice settlements concerning legal disputes.

In addition to these, there are three other ways in which European legislation supports the 'soft law status' of European technical standards. Of significance here is that they do not merely concern EU-mandated standards, but also - and perhaps first and foremost standards, which the ESO have adopted independently of the EU.

Directive on general product safety (2001/95/EEC). In the absence of provisions from the Community or member states, this directive refers to European standards for the definition of product safety. What is more, even when Community provisions exist, e.g. New Approach directives, technical standards constitute a legal source for determining a product's safety.

Public procurement. EU's directives concerning public procurement, such as 93/36/EEC, prescribe that public procurement that are covered by a directive take place in compliance with European technical standards. Should there be a lack of European technical standards for the area, the invitations to tender are to refer to international or national technical standards. ${ }^{6}$

National legislation. National legislation often refers to technical standards. European technical standards can entail that European standards supplant national technical standards' place as 'soft law'.

That European technical standards have attained a binding character can be used to argue that in conjunction they constitute a 'private product policy'. There is talk of a policy

\footnotetext{
${ }^{6}$ The directives on public procurement have been under revision and adopted recently (February 2004), but at the time of writing not yet published in the Official Journal. For further information, check $\mathrm{http} / / /$ europa.eu.int/rapid/start/cgi/guesten.ksh?p_action.gettxt=gt\&doc=IP/04/150|0|RAPID\&lg=EN\&display= and http://europa.eu.int/comm/internal_market/en/publproc/general/2k-461.htm
} 
in the minimal sense of Easton's definition, as ESO - via standards that bind in practice determines the technical specifications according to which goods in the internal market are produced and marketed.

In other words, the standards provide the most precise basis for the deciphering of the concrete rules for the marketing of products, which means that the internal market first takes its final form when the technical standards are complete and utilized - and not when the general framework legislation is passed. The boundary between that which separates common European (political) objectives and (technical) means becomes indeterminate or at least blurred - when it is not in the legislation, but rather in the technical means for its implementation that the actual conditions for competition in the internal market are to be found. As a consequence, the conditions for competition are at least partially determined in the standardization process. For it is precisely in the standardization process itself that the struggle between different interests results in de facto binding standards that have an independent influence on the shaping of the internal market.

That it is at all possible to talk about the safeguarding of political and not mere technical interests in European standardization is - seen from EU's perspective - related to the fact that ESO's independent room for maneuvering is not ex ante placed in a sufficiently solid framework so as to delimit the interests to be negotiated. New Approach does not determine the requirements for how e.g. environmental considerations are to be managed in the standardization process but rather, which overriding environmental principles the standards are to fulfill. The institution of the mandate, the purpose of which being to regulate the delineation of the boundary between the political and the technical, has therefore developed in a direction, which was neither intended nor foreseeable when New Approach was designed. The problem is reflected in practice by the fact that it is quite rare that the quality of mandated New Approach standards are challenged (Commission of the European Communities 2000 p. 30), as it is most difficult for national authorities to render probable how a standard fails to satisfy the very general formulations in the mandate: The more generally the mandate is formulated, the more difficult it will be to prove incongruities between mandate and standard. The mandate was nevertheless the most important instrument to ensure EU's political regulation of ESO's activities. 
It is still the EU that composes the mandate through the Commission, and the EU therefore principally maintains the political control of the standardization activities according to New Approach, but in practice the EU has limited opportunity to determine which markets the designed standards contribute to the establishment of. It is in the standardization processes in ESO that the concrete decisions about which rules are to be effective in the internal market are made between participants in the individual standardization committees, i.e. TC's and WG's.

In relation to both the ESO and the EU several signs can be identified, which indicate an implicit recognition of the political aspects of standardization processes.

Throughout the past 15 years, ESO has taken various initiatives, the purpose of which would appear to facilitate an inclusion of the broadest possible circle of considerations and interests in European technical standardization. CEN has, among other things, established various standing committees since the end of the 1980s whose purpose is to monitor and coordinate standardization activities with significance for the environment (CEN 1992) and also in 1999 established an internal 'environmental help desk'. ${ }^{7}$ Such initiatives indicate that CEN has acknowledged the need for broadening - and attempts to increase the number of - participating interests in European standardization. It reflects recognition of the fact that the organizations' activities stretch beyond narrow industrial interests and have significance in relation to the realization of broader, common European political objectives. $^{8}$

The EU's implicit acknowledgement of the political aspects of the European standardization processes can be illustrated with the help of two examples. Firstly, various documents since 1987 have raised questions as to whether general conditions in the standardization processes ought to be reformed. Without changing the formal procedures in New Approach, which states, as mentioned above, that the EU cannot specify requirements concerning the standards drafting process, but only their content, initiatives have been taken to develop a more close cooperation between the parties. One example

\footnotetext{
${ }^{7}$ Cf. www.cenorm.be/cenorm/news/pressreleases/ehd.asp

${ }^{8}$ It should be noted, however, that where recognition in principle of the political character of the processes could be justified on the one hand it would, on the other hand, be considerably harder to demonstrate the actual political influence on the standardization activities of, for example, environmental interest. For a discussion, see Führ (1996).
} 
is the Commission's so-called Framework Partnership Agreement (FPA/CEN/ENTR/2004) with CEN, which amongst others sets the conditions under which CEN may subcontract work to other organizations. Another example is the recent update of the guidelines for cooperation between the Commission, EFTA and ESO. ${ }^{9}$ These guidelines underlines that the cooperation is based on the distinct responsibilities and competencies of the parties (section 4). In substantial terms, the common denominator for these initiatives has been how to ensure a more equal representation of interests in the European standardization work and how the range of interests can be broadened. ${ }^{10}$

These initiatives not only demonstrate the awareness in the EU concerning the interests that in practice have an influence over the shaping of the common European standards, but similarly also that technical standardization is increasingly tied to the realization of EU's political objectives above and beyond product regulation. The purpose of the initiatives would therefore appear to be a general influencing of the ESO to ensure a more symmetrical representation of interests.

Secondly, the EU has actively supported the participation of 'weak' interests in ESO's activities (Environmental Resources Management 1997 p. 53). This encompasses an almost total financing of the 'technical offices' for both consumers and wage earners who are responsible for managing and coordinating the participation of interests in European standardization. ${ }^{11}$ The example shows how the EU has taken strides to establish a more symmetrical safeguarding of interests in the ESO.

Together, the EU and ESO reform initiatives seem to imply an acknowledgement of the fact that European standardization does not automatically lead to a broad weighing of interests; that a failure to create more symmetrical safeguarding of interests in the ESO can result in greater costs for the realization of the EU's political objectives; and that the

\footnotetext{
${ }^{9}$ In full referred to as General Guidelines for the Cooperation between CEN, CENELEC and ETSI and the European Commission and the European Free Trade Association (2003/C 91/04).

${ }^{10}$ A recent example is $\operatorname{COM}(2004) 130$ final on "Integration of environmental aspects into European standardization."

${ }^{11}$ Four interest groups have specific technical bureaus financially supported by the Commission. These are the European Trade Union Technical Bureau for Health and Safety (TUTB), the European Association for the Co-ordination of Consumer Representation in Standardisation (ANEC), the European Office of Crafts, Trades and SMEs for Standardisation (NORMAPME), and the European Environmental Citizens Organisation for Standardisation (ECOS). For an overview over the Commission's support to these bureaus, see http://www.dn-lokal.dk/ekspertfora/artikler/enviromental.html
} 
standardization process itself cannot, therefore, merely be perceived as a purely technical process, but instead must also be considered to encompass political prioritization and negotiation processes. Apart from the de facto binding character of European technical standards, this politicization of the standardization process presents yet another argument reinforcing the claim that the ESO's activities can be described in terms of a 'private product policy'.

In terms of the policy field, we can now claim to have found empirical indications suggesting that such a field has gradually been constituted on the basis of the conditions established with New Approach. First and foremost, a policy field for the internal market for products has developed in the sense that in the period following the adoption of the Single European Market Program problems have been identified in distinguishing 'purely' political from 'purely' technical considerations. The fundamental assumption in New Approach that the formulation of EU political objectives for the marketing of products in the internal market could be clearly separated from the formulation of the technical specifications for their realization - has itself been problematized. The ideal that the political 'What do we want?' is institutionally as well as organizationally distinguishable from the technical 'How do we do it?' has been contested. The 'essential requirements' for products' health, safety, and environmental protection specified in New Approach directives do not automatically, as it were, serve as a 'table of conversion' that can be used for hammering out a set of corresponding detailed product specifications. Formulating the 'table of conversion' must itself be part of the process bridging political objectives and technical solutions or possibilities, and this involves making decisions, which in practice involves a re-negotiation of the boundary between public policy and private technology. In New Approach the formal discretion to make such decisions is left with the Commission (who formulates the standardization mandates), but the Commission depends on ESO to make the decisions. In order to formulate a mandate, the Commission must consult with ESO, because only ESO can reflect on the specific technical possibilities for concretizising general/essential political requirements.

What we see, then, is a 'drifting' of political considerations across the very boundary that was initially set to separate the political from the technical. A policy field is constituted to the extent that mutually autonomous actors struggle over something, which is common to 
them and this seems to be the case here insofar as actors both within the (public) EU and the (private) ESO participate in the creation of an internal market for products. In addition, a particular form of organization has emerged in which the EU holds a public authority to define the scale and scope of standardization activities in relation to the legislative basis for the internal market, but where the ESO simultaneously has acquired a private 'authority' to define de facto binding rules and regulations (i.e. standards) for market behavior, thus constituting a 'private product policy'. Finally, in terms of modes of interaction, the policy field seems to be characterized by a formal structure of 'hard' regulation, as defined in New Approach, combined with an informal practice of 'soft' coordination, particularly reflected in the negotiation of standardization mandates. One might claim that the practice of soft coordination has emerged as a solution to the institutional problem generated by the perceived 'failure' of the formal structure for interaction.

\section{The transnational challenge}

Our account indicates that the formal forms of coordination that were originally laid out as a part of New Approach do not correspond to the actual forms of coordination. Firstly, it has become apparent that standards have a de facto binding character, although the intention was that they were to continue to be voluntary. Secondly, ensuring the political regulation of ESO's activities has only been a partial success, even though this was a premise for the division of labor.

This has led to the emergence of a 'private product policy' that reflects a transnationalization of the conditions for the EU's internal market policy. This is first and foremost owing to the fact that discrepancies exist between the EU's policies and the 'private product policy'. The differences are anchored in the fundamental boundary between the public and the private, which in New Approach is designed as a division between politics and technology. 
Transnationalization has thus emerged from the different ways in which coordination has evolved and mutual dependence has been created across this boundary. ${ }^{12}$ At the same time, the forms that coordination runs through in practice (New Approach, in particular) do not necessarily ensure congruity among policies. The decision-making processes, although formally regulated by the five-step procedure in New Approach, in practice seem to take the form of language and negotiation games, the outcome of which depends on the strategic interactions of participating actors spread across different organizational contexts. Therefore, transnationalization involves a challenge in the sense that the institutional authority and organizational locus for decision-making in relation to the realization of EU's political objectives cannot be assumed beforehand. Below, we will substantiate these claims.

A New Approach directive's requirements are undecided until the technical standards have been formed. The directives' 'double paths of implementation' (via the Community's legislation and via standards) means that there is no certainty as to how the directives come to function before the harmonized standards have been adopted. To the contrary, the legislation will have weak effects in the event that technical standards are not worked out.

The adoption of a New Approach directive is therefore not the conclusion of a political process. Rather, it is only one stage among many that span in one end from the Commission's preparation of a directive proposal to the adoption of the technical standards in the other end. Every conclusion of the game is merely temporary, as ESO can always re-start the game, e.g. by revising standards. So while the Commission with the help of deadlines in the mandate can exert a reasonable influence on when the standardization process is completed, the EU does not have control over when and how ESO re-starts the game again.

There would therefore appear to be grounds for the claim that although New Approach was motivated by a vision of insuring EU's political objectives via ESO's technical means,

\footnotetext{
${ }^{12}$ This view is analytically consistent with the definition of transnational relations proposed by Risse-Kappen (1995 p. 1) as "... regular interactions across national boundaries when at least one actor is a non-state agent or does not operate on behalf of a national government or an intergovernmental organization." See also Keohane and Nye (1970).
} 
these technical means have themselves developed in a direction that can have an independent influence on which political objectives become fulfilled. Even though the 'private product policy' neither directly (in terms of its content) nor indirectly (in terms of how it regulates market behavior) can be said to stand in formal opposition to EU legislation, it would nevertheless appear to bear an independent influence on the shaping of the internal market, which can be discerned from the legislation.

The means by which European standards have a binding character are not merely limited to EU-mandated standards (e.g. according to New Approach), but also include standards developed as a result of ESO's own initiative. The governance problems related to the mandated standardization activity must therefore be regarded in light of the fact that nonmandated work represents ca. 80\% of the activities in ESO's largest organization, CEN. As opposed to the mandated work, from the very outset the non-mandated work lies outside of the EU's direct political influence and thereby makes the governance problems more apparent.

The consequence is that ESO has significant room to maneuver, both because the lion's share of their activities are not formally tied to EU's political objectives and because ESO constitutes autonomous organizations with their own perceptions of the obligations that EU-mandates imply. ESO's independent maneuvering room does not necessarily mean, however, that they act in conflict with EU's political objectives. This is owing to the informal soft coordination of the EU and ESO - it is in this soft coordination, taking place in ongoing language and negotiation games, that it is continuously determined what the formal coordination means for the cooperative efforts of creating and maintaining the internal market. In this sense, New Approach created a formal system of limited hierarchical coordination between two mutually independent actor constellations that today provides the occasion for transnational coordination and bargaining games 'in the shadow' of that hierarchy. ${ }^{13}$ Although the 'shadow activity' is justified by reference to the same overall

\footnotetext{
${ }^{13}$ Although here we use Fritz Scharpf's metaphor 'in the shadow of hierarchy' (1994) (which he originally developed on the basis of Mnookin and Kornhauser (1979)), we do not imply - like he would - that the EU, i.e. the Commission, could unilaterally impose its preferred decisions if the attempts to reach a negotiated agreement with the ESO should fail. Here, 'in the shadow of hierarchy' is merely meant to illustrate that New Approach established institutional and organizational conditions for a hierarchical coordination between EU's political objectives and ESO's technical means, and that today this hierarchical relationship casts a shadow of informal, soft, and transnational coordination activity.
} 
political objective of New Approach, namely the creation of the internal market, however, this soft coordination occurs under other conditions and through other processes than those that serve as the basis for New Approach, and it is the development of these conditions and processes that we collectively conceptualize as 'transnationalization' in this paper.

The informal forms of coordination come about as a result of a constant interplay between EU institutions, EU member states, and the national and European standardization organizations. We will illustrate this in the following with the help of two brief examples, which each in their own way demonstrate not merely how New Approach's formal procedures for coordination are implemented, but also how the realization of the EU's political objectives depend on transnational forms of coordination and interplay in the shadow of New Approach.

\section{EMAS}

In 1993 the EU adopted a regulation establishing a Community scheme for industrial corporations' voluntary implementation of eco-management and auditing (EMAS) ${ }^{14}$. EMAS was a new regulatory instrument in EU's environmental policy, the purpose of which was to make corporations responsible via systematic reflection concerning the production's environmental impact, above and beyond regulative obligations. Industrial corporations (and with the new EMAS-regulation adopted in 2001 also non-industrial organizations) ${ }^{15}$ that wish to participate in the EMAS scheme must fulfill the regulation's detailed requirements, but at the same time it provides for registration in EMAS with the help of certification in accordance with EU-acknowledged environmental management standards. For this purpose, as inspired by New Approach, a mandate was issued to CEN to prepare a standard covering the regulation's requirements. With reference to its obligations arising from the so-called Vienna Agreement - entered into between CEN and the international standardization organization, ISO, in 1992 - CEN could not mount independent activities on the background of the mandate, as at that time ISO was already working on the creation of an environmental management standard (the ISO14001). This had a number of

\footnotetext{
${ }^{14}$ See Council Regulation (EEC) No 1836/93 of 29 June 1993 allowing voluntary participation by companies in the industrial sector in a Community eco-management and audit scheme.

${ }^{15}$ See Regulation (EC) No 761/2001 of the European parliament and of the council of 19 March 2001 allowing voluntary participation by organisations in a Community eco-management and audit scheme (EMAS).
} 
consequences: Firstly, CEN had to await the completion of the ISO standard. Secondly, CEN had to accept the ISO standard as the European standard. Thirdly, EU was forced to accept that its mandate was fulfilled by a different organization than that which the mandate had originally been granted to.

As a EU member state Denmark had invested much effort towards insuring the highest possible environmental requirements in the EMAS regulation. By participating (as Danish delegate) in the ISO's work the Danish Environmental Protection Agency (DEPA) became convinced that EU-recognition of the impending ISO environmental management standard would dilute the environmental requirements of the EMAS regulation. In order to ensure Danish interests in relation to the EU legislation, the DEPA, in close cooperation with the Danish standardization organization, made a high priority of participating in and influencing the private, international standardization work.

This brief example reflects that the national safeguarding of interests in the EU came to depend on private-public coordination; national authorities cannot rely solely on participation in political processes within the $\mathrm{EU}$ to attend to national interests in relation to pan-European legislation, which is closely linked to private technical standards. The conditions outlined here in relation to EMAS can also be recognized in relation to New Approach. The example shows how the coupling of European and international standardization on the one side undermines the mandate's regulatory opportunities and on the other side places greater requirements to the informal coordination, as the coordination does not merely encompass the EU and ESO, but also international standardization organizations. The coupling between ESO and international standardization (through the Vienna agreement) has been established subsequent to New Approach, and demonstrates how ESO can significantly alter the conditions for the division of labor in New Approach on the strength of their own initiatives and obligations.

\section{Council conclusion of May 181998}

At the internal market Council of Ministers' meeting May 18 1998, the efficiency in European technical standardization was criticized for being too low. Danish accounts had previously been tabled for the Council, pointing out that the development of harmonized technical standards proceeded too slowly with detrimental consequences for corporations' 
access to the internal market. Following up on the Danish initiative, the Commission presented a report at the meeting of the Council in May 1998, where it addressed the efficiency in standardization for the internal market. ${ }^{16}$ In the report the Commission concluded that the sluggishness in the development as well as the very quality of the standards were reprehensible and that the quality could first and foremost be ensured by ESO itself via the participants' voluntary involvement. In terms of improving efficiency, among other things the Commission noted

"The participation of public authorities in the standardisation process raises the question of the balance between their different roles: on the one hand, they participate in the standards making process at the same level as industry, workers, consumers, SMEs, environment interests; on the other hand, they act as an authority with a duty to protect the public interest. Once public authorities have agreed on a mandate, the search for technical solutions should in principle be left to the interested parties. In certain areas such as environment, health and safety, the participation of public authorities on a technical level is important in the standardisation process. Efficiency can be improved if the technical expertise of public authorities is present at the level of working groups." (COM(1998) 291 final, paragraph 26, emphasis in original).

Although participation in ESO's standardization activities, whether in the context of New Approach or not, strictly depends on interested parties' voluntary involvement, the Commission nevertheless emphasizes the participation of public authorities as a condition for improving the efficiency. What the Commission seems to be saying is that in practice public authorities have an implicit obligation to voluntarily participate as interested parties because their technical expertise is required to improve the efficiency in the standardization work, and hence that the standardization processes lack the participation of exactly that 'interested party', which takes the form of 'public authority' or 'public interest'. However, within the confines of the existing formal structures of interaction between the EU and ESO, i.e. the General Guidelines and New Approach, the EU (and

\footnotetext{
${ }^{16}$ See COM(1998) 291 final on 'Efficiency and Accountability in European Standardisation under the New Approach'.
} 
the Commission) has no competence to instruct ESO and national authorities to comply with such an 'obligation' to participate.

On this background, the Council concluded that the realization of the internal market - in terms of time and environmental requirements, among other things - depended on how the ESO itself managed its share of the division of labor. The Commission was not given further assignments to ensure that the EU's political interests were met within ESO, because the Council did not perceive itself as being able to solve the problems that were raised in connection with the effective use of New Approach. Instead, the strategy of the Council of Ministers was to attend to the EU's political interests by calling not on ESO but on the EU member states:

"...whilst recognising the voluntary nature of standardisation, to call on the national standards bodies to encourage further steps by the European Standards organisations to improve the delivery of harmonised standards in support of the New Approach Directives." (Council Conclusions, 18.th May 1998, PRES/98/148)

In this example, the realization of EU's interests vis-à-vis ESO 'took a detour' in relation to the five step formal coordination procedure determined in New Approach. Instead of coordinating on the European level, between EU and ESO with the Commission as an intermediate, the ball was passed forward to the national authorities to utilize national standardization organizations to attend to EU's political objectives in relation to ESO. In this context, the Council of Ministers acted as the coordinating organ for EU member states' national efforts in relation to European standardization.

\section{Conclusion}

In this paper we have shown that the EU's internal market policy has undergone a reorientation, which to a certain extent has taken place both parallel to and in potential conflict with the development of the private product policy. This seems to have changed the conditions for the realization of EU and member state as well as private actor political interests in relation to European integration. 
For the EU as a whole, New Approach directives is a tool that eases the workload in producing detailed legislation. The division of work was a solution to the problem that technical details were politizised in Council negotiations and therefore blocked the adoption of legislation. The solution invigorated the integration process by adopting framework directives with wide consequences. However, the solution also seems to have been re-introduced as a problem that requires new solutions.

We have summed up the changed conditions with the concept of transnationalization, which has led to a systematic integration of private actors into the political arena where European integration is determined. The transnational conditions challenge the assumptions behind the division of work on at least three accounts.

First, the coordination of EU and ESO activities not only takes place through the mandating and approval of technical standards but also in a context of political negotiations on what objectives could and should be pursued by which means. Second, national standards organizations not only pursue technical considerations in the European market creation process but also political interests. Third, apart from EU-internal interest intermediation, national authorities have to address public-private interaction with national standards organizations in order to secure political objectives in the integration process.

The overall empirical conclusion can therefore be summed up by claiming that the coordination within EU institutions of political objectives with the internal market is not necessarily governing the actual process of market creation. In other words, the internal market emerges in a game, where EU institutions participate as one among many actors and where no single actor - individual or collective - can determine the outcome. This point becomes clear when public-private coordination in the standardization system creates partial conditions for the establishment of the internal market for products.

In the paper, we have shown that the delegation of 'technical competencies' to ESO in 1987 has not lived up to the expectations on which the delegation was originally based; that the EU control of ESO activity allows for a significant, independent line of action for ESO; and that the architecture of the internal market for products is therefore established 
in transnational negotiations, where public authorities and private actors participate on equal grounds.

These observations have been made on the basis of an analytical approach using the category of policy field as its main element. The question now is to what extent the approach has proved fruitful in diagnosing the conditions for private actor political enterprise in relation to European integration. In order to answer this question we need to go back to what motivated the paper in the first place. In our view, much theorizing on European integration takes as its point of departure analytical models, in which the boundary between the public and private is conceptualized in accordance with notions of the liberal, democratic state of law. Within this notion, politics and political agency is institutionally and organizationally defined as pertaining to the public sphere of activity. As a practical belief this notion is extremely important as it so obviously shapes behavior, which hopefully has been demonstrated in our analysis. However, as a starting point for scientific observation it seems more problematic, since it involves an inherent ontologizing of the public-private boundary. If we build our theories of European integration on the basis of a conceptualization that reify this boundary and we therefore accept that the boundary is an ontological condition for the observation of politics, we might at best offer alternative perspectives and fashionable conceptualizations in the light of which political practice might reorient itself. But at the same time, we will be unable to analyze how politics emerges through the very process of ontologizing the boundary between public and private.

In order to identify the emergence of politics and how it organizes the distinction between the public and the private, we have taken as our point of departure a 'minimal' definition of politics along the Eastonian lines of 'collectively binding decisions'. On the one hand, this definition gives us an initial 'clue' as to what we are looking for, but on the other hand, it is sufficiently 'empty' in the sense that we have not a priori defined what we mean by 'collective', 'binding', and 'decision'. In a similar vein, we have developed the analytical concept of a policy field to address the contextual as well as procedural conditions under which politics and political agency is studied. The application of the policy field category does not in advance specify which institutional and organizational boundaries are subject 
for what form of political struggle - it only implies that institutional and organizational boundaries are at stake in making collectively binding decisions.

Our analysis has shown that in the context of creating an internal market for products political identities organized on the basis of public authority play an important, and perhaps even dominant, role in making decisions constituting the conditions for market behavior. However, our analysis has also shown that actors organized on the basis of private technological competence make political decisions that bind market behavior. What we have seen then, is that the internal market for products is constituted by an intricate transnational game where individual actors can assume different identities and appeal to different forms of authority. For example, as we have shown in section five above, the Danish Environmental Protection Agency, participated in this transnational game by switching between the roles of EU member state representative and national public authority within the EU, and as private Danish delegate in European and international technical standardization. The different kinds of political, technological, territorial, public, and private authority the DEPA exercised by participating in these different organizational contexts seem to indicate that the very concept of authority is at stake in the transnational game. If authority can be meaningfully exercised in a multitude of different forms that function - as it were - on an equal basis we need to develop analytical strategies that open the study of the ways in which such forms of authority emerge as a result of political struggle, and what effects these struggles have for the reproduction and constitution of boundaries - public/private, politics/technology, national/European etc.

In this paper, we hope to have presented an argument that justifies the opening of a new avenue of scientific attention in relation to European integration. As we stated in the introduction, this is just a first step in that direction. Therefore, we should proceed with caution, taking into account that the value of the analytical categories developed and the evaluation of the examples presented will ultimately rest with further and much more vigorous empirical studies producing relevant evidence, or - as it were - counterevidence. In this respect, this paper only purports to suggest a possible research agenda. 


\section{Literature}

Abbott, Kenneth W. \& Duncan Snidal (2001). International 'standards' and international governance. Journal of European Public Policy, 8, 3, pp. 345-370.

Andersen, Niels Åkerstrøm (2003). Discursive Analytical Strategies - Understanding Foucault, Koselleck, Laclau, Luhmann. Bristol: Policy Press.

Bourdieu, Pierre (1994). In Other Words - Essays Towards a Reflexive Sociology. Stanford, CA.: Stanford University Press.

Bourdieu, Pierre \& Loïc D. J. Wacquant (1992). An Invitation to Reflective Sociology. Cambridge: Polity Press.

Broady, Donald (1991). Sociologi och epistemologi. Om Pierre Bourdieus författerskap och de historiska epistemologin. Stockholm: HLS-Förlag.

Börzel, Tanja (1998). Organizing Babylon - On the Different Conceptions of Policy Networks. Public Administration, 76, 2, pp. 253-273.

Börzel, Tanja \& Thomas Risse (2001). Private-Public Partnerships: Effektive and Legitimate Tools of International Governance? Prepared for the Workshop on "Global Governance", 6-7 April 2002. Florence: EUI RSCAS.

Campbell, John L. \& Ove K. Pedersen (Eds.) (2001). The Rise of Neoliberalism and Institutional Analysis. Princeton: Princeton University Press.

CEN (1992). Environmental Standardization by CEN. Consultation Document 11. Bruxelles: CEN.

Chisholm, Donald (1989). Coordination without Hierarchy - Informal Structures in Multiorganizational Systems. London: University of California Press.

Commission of the European Communities (2000). Guide to the Implementation of the Directives Based on New Approach and Global Approach. Luxembourg: Office for Official Publications of the European Communities \& http://europa.eu.int/comm/enterprise/newapproach/newapproach.htm.

Dehousse, Renaud (1998). Law Implementation in a Polycentric Community: Towards a Regulation of Transnational Governance?, CORE Conference on "Rethinking Constitutionalism in the European Union", March 19-20, 1998, Schæffergården, Denmark.

DIN (1995). Europaeische Normung. Ein Leitfaden des DIN. Berlin: DIN.

Dowding, Keith (1995). Model or Metaphor? A Critical Review of the Policy Network Approach. Political Studies, 43, 1, pp. 136-158.

Easton, David (1981). The Political System - An Inquiry Into The State of Political Science. Chicago: University of Chicago Press. 
Environmental Resources Management (1997). Analysing the Participation of Environment NGOs in the Standardisation Process: (Ref. B4-3040/96/000469/MAR/E4). Report commissioned by Directorate-General for Environment, Nuclear Safety and Civil Protection. London: Environmental Resources Management Ltd.

Fligstein, Neil (1996). Markets as politics: a political-cultural approach to market institutions. American Sociological Review, 61, 4 August, pp. 656-673.

Fligstein, Neil \& Iona Mara-Drita (1996). How to Make a Market: Reflections on the Attempt to Create a Single Market in the European Union. American Journal of Sociology, 102, 1, July, pp. 1-33.

Fuchs, Gerhard (1994). Policy-Making in a System of Multi-level Governance - the Commisssion of the EC and the Restructuring of the Telecommunications Sector. Journal of European Public Policy, 1, 2.

Führ, Martin (1996). European Standardization Procedures: A Model for Reform. Environmental Law Network International, 2, pp. 22-27.

Goldschmidt, Lars (1995). Internationalt standardiseringsarbejde: En udfordring for miljøadministrationen. In Lübcke, Poul (Ed.), Miljøet, markedet og velfærdsstaten, (pp.445-471). København: Fremad og AIF.

Gorges, Michel J. (1996). Euro-corporatism? Interest intermediation in the European Community. Lanham, Md.: University Press of America.

Joerges, Christian, Karl-Heinz Ladeur \& Ellen Vos (Eds.) (1997). Integrating Scientific Expertise into Regulatory Decision-Making. Baden-Baden: Nomos Verlagsgesellschaft.

Joerges, Christian, Harm Schepel \& Ellen Vos (1999). The Law's Problems with the Involvement of Non-Governmental Actors in Europe's Legislative Processes: The Case of Standardisation under the 'New Approach'. EUI Working Paper LAW No. 99/9. Badia Fiesolana, San Domenico: European University Institute.

Jörissen, J. (1996). TA-Projekt "Möglichkeiten und Probleme bei der Verfolgung und Sicherung nationaler und EG-weiter Umwetschutzziele im Rahmen der europäeischen Normung". Endbericht. Bonn: Büro für Technikfolgen-Abschaetzung beim Deutschen Bundestag.

Keohane, Robert O. \& Joseph S. Nye (1970). Transnational Relations and World Politics. Cambridge, Mass: Harvard University Press.

Kickert, Walter J., Erik-Hans Klijn \& Joop F. M. Koppenjan (Eds.) (1997). Managing Complex Networks - Strategies for the Public Sector. London: SAGE.

Kohler-Koch, Beate \& Rainer Eising (1999). Governance in the European Union: A Comparative Assessment. In Kohler-Koch, Beate \& Rainer Eising (Eds.), The Transformation of Governance in the European Union, Routledge/ECPR studies in European political science 12, (pp.267-285). London: Routledge. 
Marks, Gary (1992). Structural Policy and 1992. In Sbragia, Alberta M. (Ed.), Europolitics, (pp.191-224). Washington D.C.: Brookings.

Marsh, David \& R. A. W. Rhodes (1992). Policy Communities and Issue Networks Beyond Typology. In Marsh, David \& R. A. W. Rhodes (Eds.), Policy Networks in British Government, (pp.249-268). Oxford: Clarendon Press.

Mattli, Walter (2001). The politics and economics of international institutional standards setting: an introduction. Journal of European Public Policy, 8, 3, pp. 328-344.

Mazey, Sonia \& Jeremy Richardson (1993a). Environmental Groups and the EC: Challenges and Opportunities. In Judge, David (Ed.), A Green Dimension for the European Community: Political Issues and Processes , (pp.109-128). London: Frank Cass.

Mazey, Sonia \& Jeremy Richardson (Eds.) (1993b). Lobbying in the European Union. Oxford: Oxford University Press.

Mnookin, R. H. \& L. Kornhauser (1979). Bargaining in the Shadow of the Law: The Case of Divorce. Yale Law Journal, 88, 5, pp. 950-997.

Pedersen, Ove K. (1991). Nine Questions to a Neo-institutional Theory in Political Science. Scandinavian Political Studies, 14, 2, pp. 125-148.

Pedersen, Ove K. \& Dorthe Pedersen (1995). The Europeanization of National Corporatism - When the State and Organizations in Denmark went to Europe together. COS-forskningsrapport 4/1995. København: Center for offentlig Organisation og Styring.

Pedler, Robin H. (Ed.) (2002). European Union lobbying - Changes in the arena. London/Basingstoke: Palgrave Macmillan.

Peters, Guy (1992). Bureaucratic Politics and the Institutions of the European Community. In Sbragia, Alberta M. (Ed.), Europolitics, (pp.75-122). Washington D.C.: Brookings.

Peters, Guy (1994). Agenda-setting in the European Community. Journal of European Public Policy, 1, 1 June, pp. 9-26.

Peterson, John (1995). European Union: Towards a Framework for Analysis. Journal of European Public Policy, 43, 1, pp. 69-94.

Peterson, John \& R. A. W. Rhodes (1992). The European Technology Community: Policy Networks in a Supranational Setting. In Marsh, D. (Ed.), Policy Networks in British Government, (pp.226-248). Oxford: Clarendon Press.

Porter, Martin (1997). Cross-National Policy Networks and the EU's Packaging and Packaging Waste Directive. In Liefferink, Duncan \& Mikael Skou Andersen (Eds.), The Innovation of EU Environmental Policy, (pp.83-110). Copenhagen: Scandinavian University Press. 
Rhodes, R. A. W., Ian Bache \& Stephen George (1996). Policy Networks and PolicyMaking in the European Union: A Critical Appraisal. In Hooghe, Liesbet (Ed.), Cohesion Policy and European Integration: Building Multilevel Governance, (pp.367-387). Oxford: Oxford University Press.

Richardson, Jeremy (1995). EU Water Policy. Uncertain Agendas, Shifting Networks and Complex Coalitions. Environmental Politics, 3, 4, pp. 139-167.

Risse-Kappen, Thomas (Ed.) (1995). Bringing Transnational Relations Back In: Non-State Actors, Domestic Structures, and International Institutions. Cambridge: Cambridge University Press.

Scharpf, Fritz W. (1994). Games Real Actors Could Play: Positive and Negative Coordination in Embedded Negotiations. Journal of Theoretical Politics, 6, pp. 27-53.

Scheel, Kurt C. (1996). Umweltschutz und Europäische Normen - Verweisung auf Europäische Technische Normen in der Rechtssetzung der Europäischen Union. Arbeitsdokument, Reihe Umweltfragen, Volksgesundheit und Verbraucherschutz, W-16. Luxembourg: Europäisches Parlament, Generaldirektorat für Forschung.

Schneider, Volker, G. Dang-Nguyen \& Raymund Werle (1994). Corporate Actor Networks in European Policy-Making: Harmonizing Telecommunications Policy. Journal of Common Market Studies, 32, 4, pp. 473-498.

Snyder, Francis (1994). Soft Law and Institutional Practice in the European Community. In Martin, Stephen (Ed.), The Construction of Europe. Essays in Honour of Emile Noël, (pp.197-225). Dordrecht: Kluwer Adademic Publishers.

Vad, Torben Bundgaard Pedersen (1998). Europeanisation of Standardisation - European Institution Building and National Persistence in the Area of Technical Standardisation. LS 1998/1. Copenhagen: Institute of Political Science, University of Copenhagen.

Voelzkow, Helmut (1996). Private Regierungen in der Techniksteuerung. Eine sozialwissenschaftliche Analyse der technischen Normung. Schriften des Max-PlanckInstitut für Gesellschaftsforschung, Köln, Frankfurt a.M.: Campus.

Vos, Ellen (1999). Institutional Frameworks of Community Health and Safety Legislation: Committees, Agencies and Private Bodies. Oxford: Hart Publishing.

Willke, Helmut (1992). Ironie des Staates - Grunlinien einer Staatstheorie polycentrischer Gesellschaft. Frankfurt am Main: Suhrkamp. 